\title{
First confirmed record of Feresa attenuata (Delphinidae) for the Northern Brazilian Coast
}

\author{
Fagner Augusto de Magalhães ${ }^{1,2,6}$, Rosana Griselda Garri', Carolina Herédia Tosi', Salvatore Siciliano ${ }^{3}$, \\ Sathyabama Chellappa ${ }^{2}$ \& Flavio José de Llima Silva ${ }^{4,5}$ \\ Biota Neotropica v7 (n2) \\ http://www.biotaneotropica.org.br/v7n2/pt/abstract?short-communication+bn03507022007
}

Recebido em 21/12/06

Versão Reformulada recebida em 15/05/07

Publicado em 29/06/07

\author{
${ }^{1}$ Projeto Cetáceos do Maranhão, Instituto Ilha do Caju, \\ Av. Presidente Vargas, 235, Centro, CEP 64200-200, Parnaíba, PI, Brazil, \\ e-mail:cetaceoss@yahoo.com.br,tosicarol@yahoo.com.br \\ ${ }^{2}$ Programa de Pós-graduação em Ciências Biológicas, Centro de Biociências, Universidade Federal do Rio \\ Grande do Norte-UFRN, 1524, Campus Universitário Lagoa Nova, CEP 59072-970, Natal, RN, Brazil \\ e-mail: bama@dol.ufrn.br \\ ${ }^{3}$ Grupo de Estudos de Mamíferos Marinhos da Região dos Lagos - GEMM/Lagos, \\ Escola Nacional de Saúde Pública/FIOCRUZ \\ Rua Leopoldo Bulhões, 1480-térreo, Manguinhos, CEP 21041-210, Rio de Janeiro, RJ, Brazil \\ e-mail: sal@ensp.fiocruz.br \\ ${ }^{4}$ Centro Golfinho Rotador, CP 49, CEP 53990-000, Fernando de Noronha, PE, Brazil \\ e-mail: flaviogolfinho@yahoo.com.br \\ ${ }_{5}^{5}$ Departamento de Ciências Biológicas, Universidade Estadual do Rio Grande do Norte, \\ CEP 59600-970, Mossoró, RN, Brazil \\ ${ }^{6}$ Autor para correspondência: Fagner Augusto de Magalhães, e-mail: fagneramagalhaes@yahoo.com.br
}

\begin{abstract}
Magalhães, F.A., Garri, R.G., Tosi, C.H., Siciliano, S., Chellapa, S. \& Silva, J.L. First confirmed record of Feresa attenuata (Delphinidae) for the Northern Brazilian Coast. Biota Neotrop. May/Aug 2007 vol. 7, no. 2. http://www.biotaneotropica.org.br/v7n2/pt/abstract?short-communication+bn03507022007. ISSN 1676-0603.

In Brazil only one confirmed stranding is known from an emaciated specimen collected along the southeastern coast. The aim of this work is to report a recent record of a pygmy killer whale from the coast of Maranhão State, northern Brazil. On 22 October 2005, through regular surveys conducted by Projeto Cetáceos do Maranhão team, a beach-worn skull of a pygmy killer whale was found on the Mangue Seco beach, at Caju Island, Maranhão State. The specimen was identified through peculiar features, such as a short beak, 11 teeth per row in the maxile and the distance between the anterorbital notch and the end of the toothrow. This stranding suggests that pygmy killer whales may use oceanic waters close to Maranhão continental shelf. This is the second confirmed stranding of $F$. attenuata for the Brazilian Coast and the first along the northern coast. The present record increases our poor knowledge on the cetacean fauna of the northern Brazilian coast.

Keywords: stranding, pygmy killer whale, Maranhão State, Brazil.

\section{Resumo}

Magalhães, F.A., Garri, R.G., Tosi, C.H., Siciliano, S., Chellapa, S. \& Silva, J.L. Primeiro registro confirmado de Feresa attenuata (Delphinidae) para o litoral norte do Brasil. Biota Neotrop. May/Aug 2007 vol. 7, no. 2. http://www.biotaneotropica.org.br/v7n2/pt/abstract?short-communication+bn03507022007 ISSN 1676-0603.

No Brasil somente um exemplar de Feresa attenuata foi coletado ao longo da costa sudeste. O objetivo deste trabalho é registrar o recente encalhe da orca-pigméia para a costa do Maranhão, litoral norte do Brasil. Em 22 de outubro de 2005, através de monitoramentos regulares conduzidos pelo Projeto Cetáceos do Maranhão, um crânio do exemplar de F. attenuata foi encontrado na praia do Mangue Seco, na Ilha do Caju, Estado do Maranhão, Brasil. O espécime foi identificado através de características peculiares, como o rostro curto, 11 pares de dentes na maxila e pela distancia entre o anterorbital e o término dos alvéolos dentares. Este encalhe sugere que a orcapigméia pode usar águas oceânicas próximas à plataforma continental do Maranhão. Este é o segundo registro de encalhe confirmado para $F$. attenuata para a costa brasileira e o primeiro para a costa norte. O presente estudo contribui com o pouco conhecimento sobre os cetáceos na costa norte do Brasil.
\end{abstract}

Palavras-chave: encalhe, orca-pigméia, estado do Maranhão, Brasil. 


\section{Introduction}

The pygmy killer whale, Feresa attenuata Gray 1874, can be found worldwide in various deep tropical and warm temperate waters and is considered as one of the least known species of small cetaceans (Caldwell \& Caldwell 1971, Ross \& Leatherwood 1994). Since records of sightings and strandings are relatively scarce in the tropical Indo-Pacific, the same deserved special attention from several authors (e.g. Perrin \& Hubbs 1969, Best 1970, Ross 1984, Van Waerebeek \& Reyes 1988, Félix et al. 1995, Chantrapornsyl 1996). In the tropical Atlantic F. attenuata has been recorded from the Florida coast (Forrester et al. 1980), the British Virgin Islands (MignucciGiannoni et al. 1999), Puerto Rico (Rodríguez-López \& MignucciGiannoni 1999), Venezuela (Bolaños \& Villarroel-Marin 2003) and Argentina (Lichter et al. 1990). The pygmy killer whale is classified as "insufficiently known" by the World Conservation Union-IUCN. In Brazil only one confirmed record was reported (Zerbini \& Santos 1997) from an emaciated specimen stranded along the southeastern coast. Siciliano et al. (2005) have reported on a possible record of a F. attenuata or a Peponocephala electra stranded on the east coast of Marajó Island, Pará State. Recent interest in cetacean conservation on the northern coast of Brazil had resulted in an increased monitoring effort, which includes field studies and documentation of stranding events. We report on a recent record of a pygmy killer whale from the coast of Maranhão State, providing additional information on the distribution of this species.

\section{Material and Methods}

A systematic cetacean survey has been carried out since 2004 by Projeto Cetáceos do Maranhão (PROCEMA), to determine and monitor strandings of cetaceans in Delta of Parnaíba a large estuarine region between Maranhão State and Piauí State. The surveys are carried out monthly with approximately 8 hours each survey, usually from 9:00 to 17:00 hours. At least two observers covered $10 \mathrm{~km}$ of sandy beaches, using field sheets and necropsy materials such as knifes and plastic bags. The researchers maintained a constant watch during the activity and record all kinds of materials that were found from an aquatic mammal specimen. When located, the osteological material was collected and information as specimen maturity were estimated based on sutures characteristics. Craniometric data were taken based on Nishiwaki et al. (1965). The skull was deposited in Caju Island Collection catalogued as CEMA 014.

\section{Results and Discussion}

Monitoring beach cast cetaceans can provide information on spatial distribution, seasonal movements and mortality (Woodhouse 1991). Data collection in long periods and stranding locations can reveal some changes on population relative abundance (Sergeant 1979). The report of cetacean strandings, in general, is an efficient method to obtain information about these animals. The development and the logistical materials to do beaches surveys may dispense the utilization of direct catch or capture of live specimens. The obtained data may be partial, and allow diverse studies (Raga et al. 1991).

During last decades there was no attempt to study stranded cetacean in Delta of Parnaíba. Strandings data for the area have been compiled primarily by personnel living and the coastal communities that kept the material; only one record was previously published.

On 22 October 2005, through regular surveys conducted by staff of Projeto Cetáceos do Maranhão (PROCEMA), a beach-worn skull of a pygmy killer whale was found on the Praia de Mangue Seco, at Caju Island ( $02^{\circ} 44^{\prime}$ S $42^{\circ} 02^{\prime}$ W), Delta of Parnaíba River, Maranhão State, Brazil. The degree of fusion of the cranial sutures suggests that this individual was physically immature. The specimen was identified through the following characteristics: short beak, eleven teeth per row in mandible and the distance between the ante-orbital notch and the end of the tooth row (Ross \& Leatherwood 1994). Cranial measurements are given in Table 1 .

Table 1. Skull measurements (in mm) of the pygmy killer whale, Feresa attenuata, stranded in Caju Island compared with the mean values obtained for the species.

Tabela 1. Medidas craniométricas (em mm) do exemplar da orca-pigméia, Feresa attenuata, encalhada na Ilha do Caju comparado com a média de valores obtidas para a espécie.

\begin{tabular}{|c|c|c|c|c|c|}
\hline & \multicolumn{2}{|c|}{$\begin{array}{c}\text { Caju Island Specimen } \\
\text { (CEMA 014) }\end{array}$} & \multicolumn{3}{|c|}{ F. attenuata* } \\
\hline & & $\% \mathrm{CBL}$ & mean & $\% \mathrm{CBL}$ & range \\
\hline Condylobasal length (CBL) & 375 & 100.0 & 378.3 & 100.0 & $(352-405)$ \\
\hline Length of rostrum & 185 & 49.3 & 178.0 & 47.2 & $(159-195)$ \\
\hline Width of rostrum at base & 120 & 3.2 & 115.3 & 30.5 & $(99-129)$ \\
\hline Width of rostrum at $60 \mathrm{~mm}$ from base & 100 & 26.6 & 99.9 & 26.4 & $(88-111)$ \\
\hline Width of rostrum at midlength & 85 & 22.6 & 89.7 & 23.7 & $(82-97)$ \\
\hline Width of premaxillaries at midlength & 57 & 15.2 & 61.9 & 16.4 & $(55-70)$ \\
\hline Preorbital breadth of skull & 220 & 58.6 & 223.9 & 59.2 & $(203-243)$ \\
\hline Postorbital breath of skull & 235 & 62.6 & 235.9 & 62.4 & $(218-261)$ \\
\hline Breadth of skull at center of orbits & 243 & 64.8 & 218.2 & 57.7 & $(199-247)$ \\
\hline Breadth of superior nares & 50 & 13.3 & 51.0 & 13.5 & $(46-59)$ \\
\hline Maximum width of premaxillae proximally & 90 & 24.0 & 94.0 & 24.8 & $(89-107)$ \\
\hline Width of brain case between temporal fossae & 160 & 42.6 & 165.3 & 43.7 & $(156-183)$ \\
\hline Length of toothrow, upper (R) & 120 & 32.0 & 119.3 & 31.5 & $(104-134)$ \\
\hline Length of toothrow, upper (L) & 115 & 30.6 & 119.7 & 31.6 & $(107-130)$ \\
\hline Height of temporal fossa (R) & 70 & 18.6 & 63.6 & 16.8 & $(59-69)$ \\
\hline Height of the cranium between basioccipital and vertex & 145 & 38.6 & 175.9 & 46.5 & $(141-195)$ \\
\hline Width of rostrum at $1 / 4$ of rostral length from the tip & 75 & 20.0 & 75.3 & 19.9 & $(70-81)$ \\
\hline
\end{tabular}

* Measurements taken in accordance to Nishiwaki et al. (1965), Best (1970), Ross (1984) and Zerbini \& Santos (1997). 
Very little is known about the distribution of $F$. attenuata and habitat requirements, and its population size has not been estimated (IWC 2005). This stranding suggests that pygmy killer whale may use oceanic waters close to Maranhão continental shelf and stranding along this site may be sporadic. This is the second confirmed stranding of $F$. attenuata for the Brazilian Coast and the first along the northern coast.

\section{Acknowledgments}

We would like to thank CAPES for financial support, Instituto Ilha do Caju and Cetacean Society International (CSI) for logistical support. Students from Projeto Cetáceos do Maranhão, Universidade Federal do Maranhão, Universidade do Estado do Maranhão have helped during field work and APA Delta do Parnaíba/IBAMA, especially to Marcio Barragana and Magnus Severo. Ignacio B. Moreno (GEMARS, Rio Grande do Sul, Brazil) confirmed the identification of the specimen.

\section{References}

BEST, P.B. 1970. Records of the pygmy killer whale, Feresa attenuata, from Southern Africa, with notes on behavior in captivity. Ann. South Afri. Mus. 57:1-14.

BOLAÑOS, J. \& VILLARROEL-MARIN, A. 2003. Three new records of cetacean species for Venezuelan waters. Caribb. Jour. Scien. 39:230-232.

CALDWELL, D.K. \& CALDWELL, M.C. 1971. The pygmy killer whale, Feresa attenuata, in the western Atlantic, with a summary of world records. J. Mamm. 52:206-209.

CHANTRAPORNSYL, S. 1996. The first record of a pygmy killer whale (Feresa attenuata) from Thailand. Phuket. Marine Biol. Center Res. Bull. 61:29-37.

FÉLIX, F., HAASE., B. \& SAMANIEGO, J. 1995. First record of pygmy killer whale, Feresa attenuata (Cetacea, Delphinidae) and dwarf sperm whale, Kogia simus (Cetacea, Physeteridae) on the Ecuadorian Continental coast. Estud. Oceanol. 14:77-85.

FORRESTER, D.J., ODELL, D.K., THOMPSON, N.P. \& WHITE, J.R. 1980. Morphometrics, parasites and chlorinated hydrocarbon residues of pygmy killer whales from Florida. J. Mamm. 61:356-360.

INTERNATIONAL WHALING COMMISSION. 2005. The South Atlantic a sanctuary for whales. In $57^{\text {th }}$ Annual Meeting of the International Whaling Commission (Governments of Argentina, Brazil and South Africa). Ulsan, Republic Korea.
LICHTER, A.A., FRAGA, F. \& CASTELLO, H.P. 1990. First record of the pygmy killer whale, Feresa attenuata, in the Southwest Atlantic. Mar. Mamm. Sci. 6:85-86.

MIGNUCCI-GIANNONI, A.A., TOYOS-GONZÁLEZ, G.M., PÉREZ-PADILLA, J., RODRÍGUEZ-LÓPEZ, M.A. \& OVERING, J. 1999. Mass stranding of pygmy killer whales (Feresa attenuata) in the British Virgin Islands. J. Mar. Biol. 80:759-760.

NISHIWAKI, M., KASUYA, T., KAMYA. T., TOBAYAMA. T. \& NAKAJIMA, M. 1965. Feresa attenuata captured at the Pacific coast of Japan in 1963. Sci. Rep. Whales Res. Inst. 19:65-90.

PERRIN, W.F., \& HUBBS, C.L. 1969. Observations on a young pygmy killer whale (Feresa attenuata) from the Eastern Tropical Pacific ocean. Trans. San Diego Soc. Nat. Hist. 15:297-308.

RAGA, J.A., RADUÁN, A., BALBUENA, J.A., AGUILAR, A., GRAU, E. \& BORELL, A. 1991. Varamientos de cetáceos en las costas españolas del Mediterraneo durante el período 1982-1988. Misc. Zool. 15:215-227.

RODRÍGUEZ-LÓPEZ, M.A. \& MIGNUCCI-GIANNONI, A.A. 1999. A stranded pygmy killer whale (Feresa attenuata) in Puerto Rico. Aquatic Mamm. 25:119-121.

ROSS, G.J.B. 1984. The smaller cetaceans of the south east coast of southern Africa. Ann. Cape Prov. Mus. 15:173-410.

ROSS, G.J.B. \& LEATHERWOOD, S. 1994. Pygmy killer whale, Feresa attenuata Gray, 1874. In Handbook of marine mammals (S.H. RIDWAY \& R. HARRISON, eds.). Academic Press, San Diego, v. 5, p.387-404.

SERGEANT, D.M. 1979. Ecological aspects of cetacean strandings. In Biology of marine mammals: insights through strandings (J.B. Geraci \& D.S. St Aubin, eds). Marine Mammal Commission Report No. MMC-77/13, Bethesda, MD, p.94-113.

SICILIANO, S., ALVES, V.C., LIMA, N.R.E., COLOSIO A.C, SOUSA \& SILVA JR., J. 2005. Ampliação do conhecimento e novas perspectivas de estudos sobre os mamíferos aquáticos da costa amazônica. In Primeiro Congresso Internacional do Piatam: ambiente, homem, gás e petróleo. Editora da Universidade Federal do Amazonas, Manaus, p.64-65.

VAN WAEREBEEK, K. \& REYES, J.C. 1988. First record of the pygmy killer whale, Feresa attenuata Gray, 1875 from Peru, with a summary of distribution in the eastern Pacific. Z. Säugetierkunde 53:253-255.

WOODHOUSE, C.D. 1991. Marine mammal beachings as indicators of population events. In Marine mammal strandings in the United States (J.E. REYNOLDS \& D.K. ODELL, eds.). Proceedings of the $2^{\text {nd }}$ Marine Mammal Stranding Workshop, Miami, Florida, p.111-116.

ZERBINI, A.N. \& SANTOS, M.C.O. 1997. First record of the pygmy killer whale, Feresa attenuata (Gray, 1874) for the Brazilian coast. Aquatic Mamm. 23:105-109. 